\title{
JG|U
}

Gutenberg School of Management and Economics \& Research Unit "Interdisciplinary Public Policy" Discussion Paper Series

\section{Do foreign workers reduce trade barriers?}

\section{Microeconomic evidence}

Martyn Andrews, Thorsten Schank and Richard Upward

October 26, 2015

\section{Discussion paper number 1516}


Contact details

Martyn Andrews

The University of Manchester

School of Social Sciences

Oxford Rd

Manchester

M13 9PL

UK

martyn.andrews@manchester.ac.uk

Thorsten Schank

Johannes Gutenberg-Universität Mainz

Fachbereich Rechts- und Wirtschaftswissenschaften

Lehrstuhl für Angewandte Statistik und Ökonometrie

55099 Mainz

schank@uni-mainz.de

Richard Upward

University of Nottingham

Room B3 Sir Clive Granger Building

University Park

Nottingham

NG7 2RD

UK

richard.upward@nottingham.ac.uk 


\title{
Do foreign workers reduce trade barriers?
}

\section{Microeconomic evidence*}

\author{
Martyn Andrews \\ University of Manchester \\ Thorsten Schank ${ }^{\dagger}$ \\ Johannes Gutenberg-Universität Mainz, IZA and LASER \\ Richard Upward \\ University of Nottingham
}

October 26, 2015

\begin{abstract}
This paper provides evidence that foreign workers reduce firms' trade costs and thus increase the probability that firms export. This informs both the literature on trade costs and the microeconomic literature on firms' export behaviour. We identify the nationality of each worker in a large sample of German establishments, and relate this to the exporting behaviour of these establishments. We allow for the possible endogeneity of an establishment's workforce by instrumenting the share of foreign workers with the regional distribution of foreign workers in the wider labour market. We find a significant effect of worker nationality on exporting which is not driven by the industrial, occupational or locational concentration of migrants. The effect is much stronger for senior occupations, who are more likely to have a role in exporting decisions by the establishment. The relationship is also stronger when we consider exports to particular regions and workers from these regions, consistent with a gravity model in which trade flows from country $i$ to $j$ are a function of migrants from $j$ in $i$.
\end{abstract}

\footnotetext{
${ }^{*}$ The comments of participants at the following presentations are gratefully acknowledged: European Association of Labor Economists (EALE) conference in Pafos (Cyprus), 4th User Conference of the Research Data Centre (FDZ) of the Federal Employment Agency at the IAB, Nuremberg, Conference on "Globalization, Organization and the Ownership of Firms", Research Institute of Industrial Economics (Stockholm), Comparative Analysis of Enterprise (Micro) Data (CAED) Conference (Nuremberg), Annual Meeting of the German Economic Association (Verein für Socialpolitik) in Göttingen, seminars at the universities of Darmstadt, Frankfurt, Kassel, Mainz, Newcastle, Nottingham, Sheffield, Trier, Tübingen and at the ETH Zurich. Much of the work for this paper was completed while Upward was visiting the Institut für Arbeitsmarkt und Berufsforschung.

${ }^{\dagger}$ Corresponding Author. Email schank@uni-mainz.de.
} 


\section{Introduction}

In their review of the large literature on trade costs, Anderson and van Wincoop (2004) conclude that trade barriers associated with national borders are large, but that policy barriers, in the form of tariff and non-tariff barriers, are only a small fraction of the total border effect. Instead, informal trade barriers are the largest component of the cost of trading goods across national borders. These barriers include language, cultural differences, information costs and contracting costs. Evidence on the importance of these informal trade barriers comes almost exclusively from studies of aggregate trade flows between countries. A separate literature has used firm- or establishment-level data to examine the factors which determine entry into export markets (e.g. Roberts and Tybout, 1997; Bernard and Jensen, 2004). The two key findings of this literature are, firstly, the importance of firm heterogeneity and, secondly, the role of sunk costs in causing persistence of exporting behaviour. These two findings interact because more productive firms are better able to overcome the sunk costs, and hence more likely to enter export markets. It is also likely that firms differ in the size of the sunk costs they face. If informal trade barriers differ between firms, this would also explain why some firms export and others do not.

This paper examines whether the presence of foreign employees can provide one explanation why some firms export and others do not. Our basic hypothesis is that firms' foreign workers can reduce trade costs, because foreign workers help establishments to overcome language, cultural and informational barriers to trade. Aggregate gravity models have established that the presence of migrants can increase trade between countries. This paper shows that this mechanism operates, at least partly, via the employees of firms. ${ }^{1}$

Using a representative panel of German establishments, we can identify both the nationality of each worker within each establishment and the exporting behaviour of these establishments. We then examine whether the proportion of foreign workers in an establishment has a causal impact on the probability of entering export markets. We deal with the potential endogeneity of the establishment's workforce by controlling for observable characteristics such as the establishment's location (including distance to the German border), size, sector as well as characteristics of workers in the establishment,

\footnotetext{
${ }^{1}$ Alternative mechanisms include the idea that migrant networks encourage trade via consumers' preferences, or that trade is facilitated by overseas agents who are external to firms.
} 
and by constructing instruments for the share of foreign workers in an establishment.

The richness of the data allow us to go beyond examining the simple hypothesis that establishments with more foreign workers are more likely to export. We test a number of related hypotheses which shed more light on the mechanism by which foreign workers affect establishments' exporting behaviour. First, we expect that employees' influence on their establishments' exporting capabilities is greater for more senior workers and workers who have a direct link to customers. Occupational information on each worker allow us to test this hypothesis. Second, we test whether establishments are more likely to export to a particular destination if they employ foreign workers from that destination.

We find robust evidence of a relationship between the proportion of foreign workers in an establishment and the probability of exporting. OLS estimates suggest that a one standard-deviation increase in the share of foreign workers in an establishment increases the probability of exporting by 1.5 percentage points. 2SLS estimates suggest that the effect is larger, about 7.5 percentage points, although these estimates are less precise. The effect is not driven by foreign workers who originate from those Southern European countries which sent large numbers of (largely unskilled) manual workers to Germany in the 1950s and 1960s under the so-called Gastarbeiter programs. An additional effect is observed for foreign workers who are in managerial positions within the establishment. Further, the effect is driven by foreign workers whose nationality matches the export destination, rather than to third-country destinations. This supports the idea that foreign workers lower export barriers to those countries from which they originate (as in a gravity model) rather than to foreign markets more generally.

The paper is organised as follows. Section 2 briefly reviews the two relevant literatures on trade costs and on firm exporting behaviour. Section 3 describes the data and presents evidence that there is a strong correlation between the nationality of workers and their establishments' exporting behaviour. Section 4 explains our econometric methods, which address the possible endogeneity of the workforce. Section 5 describes the results, and Section 6 concludes.

\section{Literature review}

Rauch and Casella (2003) argue that, "as tariffs and transportation costs have come 
down, research has increasingly focused on informal barriers to trade." These informal barriers include information, business contacts, language, contract enforcement and preferences. Of these barriers, at least the first three might potentially be mitigated by the presence of foreign workers in a firm.

At the aggregate level, there is considerable evidence of a link between trade flows and stocks of migrants. For example, Gould (1994) estimates a gravity model of trade between the US and $j=1, \ldots, 47$ trading partners. The model includes measures of the number of immigrants from country $j$, the skill intensity of those immigrants, and their average length of stay. Gould finds significant import and export effects, and also finds that only small numbers of migrants are required for the export effect, relative to import effects. He also argues that the information channel is less important for homogeneous goods where the price provides better information, and, consistent with this hypothesis, there are larger effects for less homogeneous products.

Other related evidence comes from the effect of common languages on trade. Frankel (1997, p.74) includes a dummy variable for "common language" in a gravity model and finds that countries which share a common language trade about $55 \%$ more than they would otherwise.

Hatzigeorgiou and Lodefalk (2013) provide a comprehensive summary of the empirical literature on the relationship between migration and trade. ${ }^{2}$ Of the 66 papers cited, the vast majority are at the "macro" level: that is, they measure the relationship between inter-country trade and country-level migrant stocks. ${ }^{3}$ A meta-analysis by Genc et al. (2011) suggests that the elasticity of exports from $i$ to $j$ with respect to migrant stocks from $j$ in $i$ lies in a wide range from -0.11 to 0.65 , with a mean of 0.17 (Genc et al., 2011, Table 3).

Stylised facts have also emerged about the exporting status of individual firms or establishments. The most important is that exporting and non-exporting firms co-exist in the same narrowly defined industry. Only a small proportion of firms export, a very small proportion of these are responsible for the vast majority of all exports, and those that do export generally export only a small proportion of their output. See, for example, Bernard et al. (2007). Greenaway and Kneller (2007) stress that the key

\footnotetext{
${ }^{2}$ Other recent literature reviews include Wagner et al. (2002) and Egger et al. (2012); Genc et al. (2011) also provides a meta-analysis.

${ }^{3} \mathrm{~A}$ few studies use data from within countries, including Wagner et al. (2002) who examine trade between Canadian provinces.
} 
features of models which can explain exporting decisions by firms are the interaction of sunk costs and productivity heterogeneity. But Kneller and Pisu (2008) note that we know less about how trade costs or trade barriers affect individual firms, and this is precisely what we shed light on in this paper.

As noted, almost all studies considered the effect of migration on exports using country-level or region-level data. The aggregate data cannot reveal the precise mechanism by which migrants affect trade flows. However, the availability of linked employeremployee data which contains information on firm-level exporting behaviour and the nationality of employees allows a direct test of the hypothesis that the migration effect of exporting operates via a firm's employees. ${ }^{4}$ The only previous study on the effect of foreign workers within the firm on the firm's exporting behavour is Hiller (2013), who regresses Danish firm export sales to country $j$ on the stock of migrants from country $j$ who work in the firm, and in addition the stock who reside in the region. She finds a small but significant effect of the firm's migrant employment on the firm's exports. ${ }^{5}$ To deal with the problem that the firm's stock of foreign workers is endogenous, she constructs two instruments, namely the share of foreign workers employed by other firms in the industry and the same region. The IV estimates suggest a larger (albeit less preciseley estimated) effect of foreign workers on exporting.

In this paper we provide the first evidence for Germany on the relationship between the employment of foreign workers and firms' exporting behaviour. We allow for the fact that firms' hiring decisions are in part driven by the composition of workers in the local labour market. This is the same approach used by Hiller, but in this paper we model the extensive margin of exporting, i.e. whether or not firms who hire foreign workers are able to break into those export markets.

\section{The data and descriptive statistics}

We use two datasources. The first is the Institut für Arbeitsmarkt- und Berufsforschung (IAB) Establishment Panel, an annual survey of between approximately 4,000 and 10,000

\footnotetext{
${ }^{4} \mathrm{~A}$ related literature investigates how other workforce characteristics affect firm performance, including exporting behaviour. For example, Molina and Muendler (2013) and Mion and Opromolla (2011) show that firms' hiring behaviour is an important predictor of their subsequent export performance. In particular, hiring workers who have themselves previously worked for exporters is a significant factor.

${ }^{5}$ Hiller uses the number of foreign workers in the firm, so it is difficult to interpret these results in terms of an elasticity. In addition, the number of migrants is unlikely to have a constant effect on exporting across e.g. firm size.
} 
establishments located in Western Germany (since 1993) and between approximately 4,000 and 6,000 establishments located in Eastern Germany (since 1996). The sampling frame comprises all establishments with at least one worker covered by the social security system as of 30 June in the year before the survey. The sample includes all industries, and covers approximately $1 \%$ of all establishments and approximately $7 \%$ of workers because it is weighted towards larger establishments. A more detailed description of the data is in Fischer et al. (2009). Information is obtained by personal interviews with establishment managers, and comprises about 80 questions per year on, for example, employment, bargaining arrangements, sales, exports, investment, wage bill, location, and industry.

The original sample comprises 187,434 establishment-years on 46,121 establishments over the period 1993-2008. We drop establishments whose industry is classified as: Public Administration, Membership Organisations and Private Households. We also drop establishments which are classified as "not for profit", or whose legal status is classified as a public corporation. It might be argued that some establishments in our sample produce non-tradable output, such as services which can only be delivered face-toface. We therefore exclude industries where the average percentage of exports to output is less than $1 \%{ }^{6}$ These exclusions reduce the sample to 108,557 establishment-years and 27,440 establishments.

Exports are recorded as a proportion of total sales in the previous calendar year. From 1998 onwards, exports to countries in the European Monetary Union are separately recorded. From 2004 onwards, exports to the new member states which joined the EU during the 2004 expansion are also separately recorded. We drop the small number of observations which do not contain export information, reducing the sample to 103,131 establishment-years and 26,682 establishments. Figure 1 shows the proportion of establishments in our sample which export any of their output over the sample period. A consistently higher proportion of establishments export from Western Germany, but the share of exporting establishments in Eastern Germany is catching up. ${ }^{7}$

The second source of data is the employment statistics register of the German Federal Office of Labour (Beschäftigtenstatistik), which covers all workers or trainees registered

\footnotetext{
${ }^{6}$ These sectors were: Construction, Hotels and Restaurants, Education Services, and Health Services. These establishments contributed 32,713 observations, or $17 \%$ of the original sample.

${ }^{7}$ Wagner (2008) provides detailed evidence on the proportion of manufacturing establishments exporting in Eastern and Western Germany, while Wagner (2004) discusses the increase in exports over the relevant time period.
} 
Figure 1: Proportion of establishments which export. Sample comprises 26,682 establishments. Weighted by sampling weights.

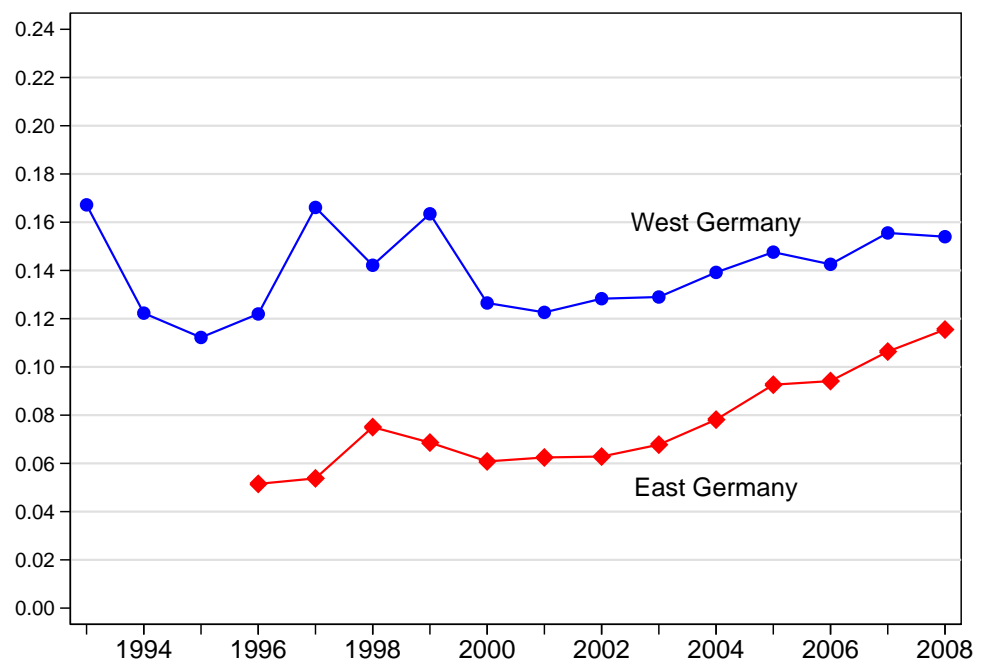

by the social insurance system. ${ }^{8}$ Almost all workers in private sector establishments are included in the register. ${ }^{9}$ Information on workers includes basic demographics, start and end dates of employment spells, occupation and industry, earnings, qualifications (school and post-school), and an establishment identification number which can be linked to the establishment identifier in the panel.

We select all workers in the employment register who are employed by the establishments in the IAB Establishment Panel on June 30th each year. We exclude apprentices, part-time workers, homeworkers and those aged over 65 or under 16 from the sample. Because the information on exporting in the IAB Establishment Panel refers to the previous calendar year, we use worker-level information from two years before the interview date. For example, the 2008 survey provides information about exporting activity from January to December 2007; this is linked to information on workers in establishments on June 30th 2006, so we can be sure that the worker information pre-dates the exporting information. ${ }^{10}$ From our sample of 103,131 establishment-years, 90,169 (87\%) can be linked to information on workers two years earlier. The remaining establishments either did not exist two years earlier, or had no employees covered by social security at that point. After dropping missing values on the explanatory variables, our final estimation

\footnotetext{
${ }^{8}$ For more details, see Bender et al. (2000).

${ }^{9}$ The Establishment Panel contains information on the number of employees and the number of employees covered by social security. In our sample of private sector establishments $96 \%$ of employees are covered by social security.

${ }^{10}$ Although 1993 is the first year of the Establishment Panel, the employment statistics register can be used to find workers in establishments before 1993, so we do not lose observations by pre-dating the worker-level information in this way.
} 
sample comprises 83,756 establishment-years (20,700 establishments).

The employment register data records the nationality (citizenship) of workers. We face two potential problems with this information. First, it is likely that some workers who are recorded as being "foreign" have lived in Germany for some time, or may even have been born in Germany. ${ }^{11}$ Germany signed bilateral recruitment agreements with Italy, Greece, Turkey, Spain, Portugal, Yugoslavia, Morocco and Tunisia in the 1950s and 1960s, and many of these workers, or even their children, may still be classified as foreign despite having weak ties to their home countries. In our empirical work we therefore focus on results which exclude these so-called Gastarbeiter. Second, Wichert and Wilke (2009) show that the nationality variable in the Beschäftigtenstatistik suffers from various misclassification errors. ${ }^{12}$ Misclassification seems possible because the information is recorded by employers who have no legal requirement to complete the information accurately. In Appendix A we document how recorded nationality can change over time for individuals in the sample, and we explain the rules we adopt to clean the data. All results in the paper are based on this cleaned nationality information. Table 1 reports the most common nationality in the sample period, ${ }^{13}$ and shows that the share of foreign workers in Gastarbeiter countries has been declining, while the share from Poland, Romania and Russia has been increasing.

There is also a wide variation in the geographical concentration of migrants, as shown in Figure 2. The importance of migrants from Gastarbeiter countries is again clear by comparing panel (a) with (b) or (c) with (d). Migrants tend to be concentrated in large cities and in districts which are near to borders with other countries. Since establishments in these locations may face systematically different barriers to exporting, we control for these geographical features.

Some basic characteristics of the establishments in our sample are given in the top panel of Table 2, split into four groups defined by the proportion of output exported. Basic patterns are consistent with those found in the firm- or establishment-level literature on exporting. Exporting establishments in our data are larger, more likely to

\footnotetext{
${ }^{11}$ German nationality is essentially based on parents' nationality, irrespective of place of birth. It has traditionally been quite difficult for non-Germans to acquire German nationality, requiring (among other conditions) a minimum of 15 years of residence. The amended Nationality Act of 2000 has made it slightly easier but still requires at least eight years of residence. Children born in Germany to nonGerman parents acquire German nationality at birth only if at least one parent has a permanent residence permit and has been living in Germany for at least eight years.

${ }^{12}$ Although their conclusion is that the nationality information is "generally reliable".

${ }^{13}$ Our sample of establishments are observed from 1993-2008, which are linked to nationality information from 1991-2006 to ensure that nationality information pre-dates export information.
} 
Figure 2: Proportion of the workforce who have foreign nationality by district in Germany in 1992 and 2006. District boundaries are Kreis, administrative units at an intermediate level between the German States (Länder) and the local municipal levels (Gemeinden).

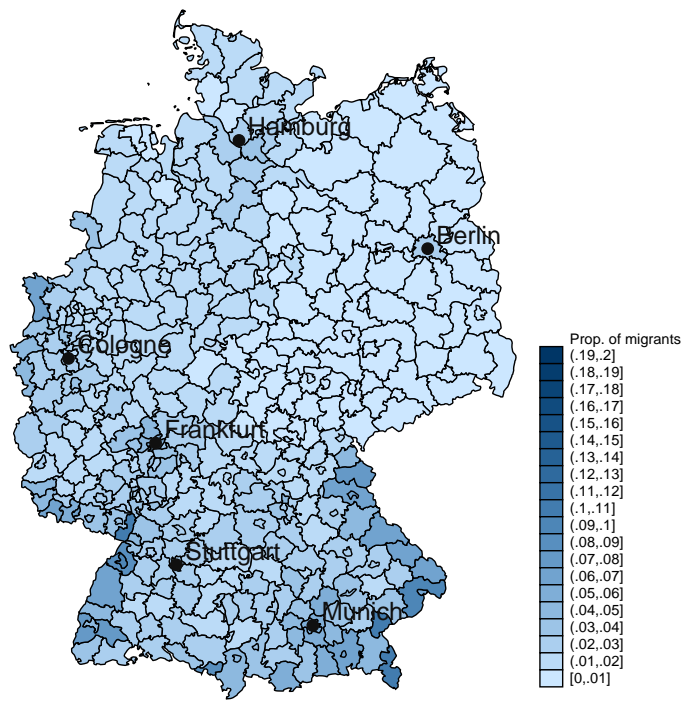

(a) 1992, excluding migrants from Gastarbeiter countries

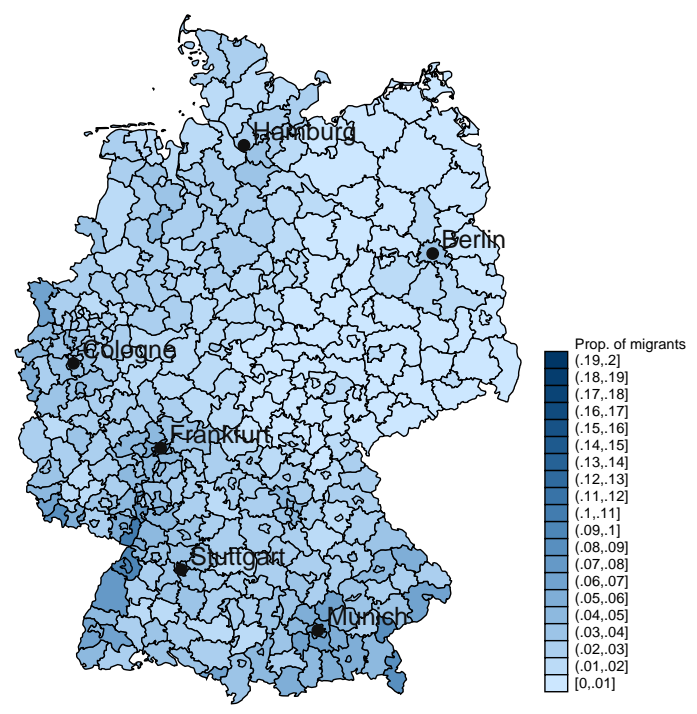

(c) 2006, excluding migrants from Gastarbeiter countries

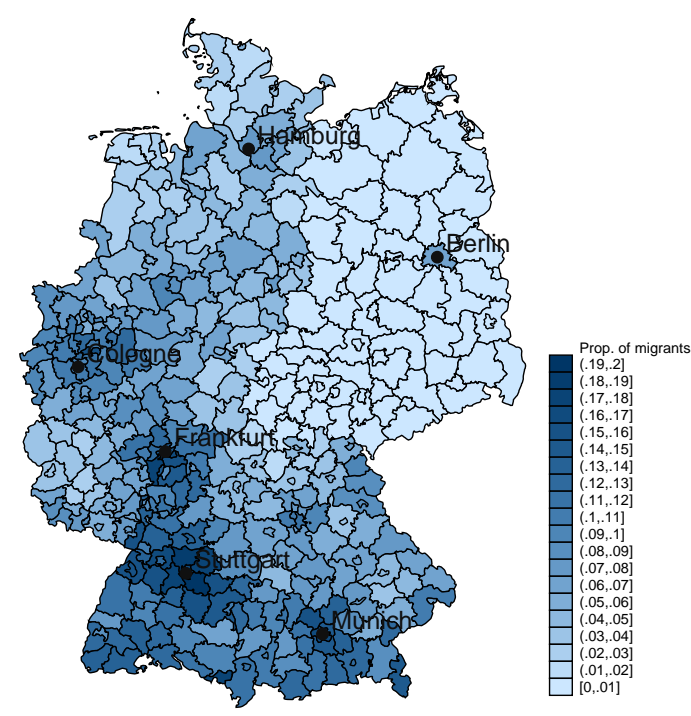

(b) 1992, all migrants

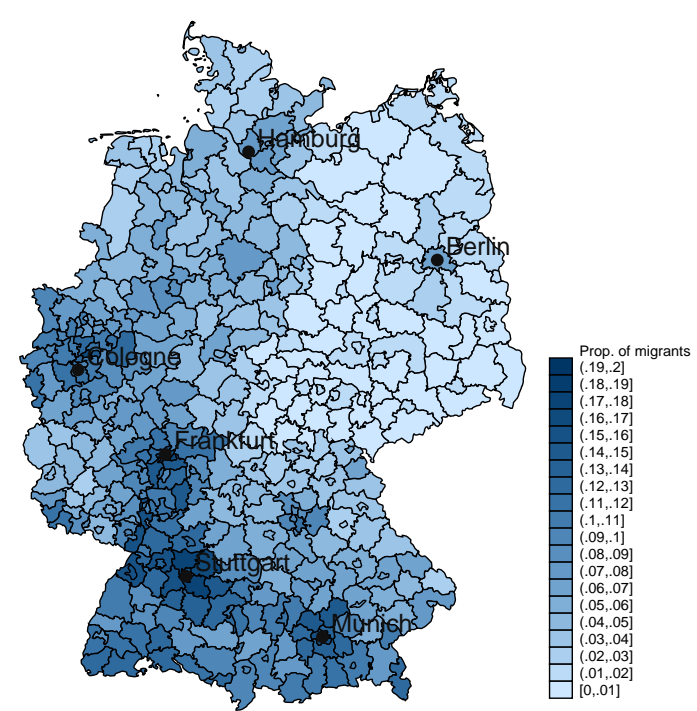

(d) 2006, all migrants 
Table 1: Percentage of the workforce in sample establishments by the most commonly occurring nationality 1991-2006.

\begin{tabular}{lrrr}
\hline & 1991 & 1999 & 2006 \\
\hline Germany & 88.40 & 91.49 & 91.35 \\
Turkey & 4.24 & 2.81 & 2.70 \\
Former Yugoslavia & 1.76 & 1.23 & 1.05 \\
Italy & 1.23 & 0.78 & 0.81 \\
Greece & 0.91 & 0.50 & 0.37 \\
France & 0.46 & 0.45 & 0.44 \\
Austria & 0.44 & 0.32 & 0.35 \\
Poland & 0.20 & 0.26 & 0.33 \\
Spain & 0.39 & 0.20 & 0.18 \\
Portugal & 0.24 & 0.17 & 0.14 \\
Netherlands & 0.17 & 0.14 & 0.14 \\
United Kingdom & 0.17 & 0.13 & 0.13 \\
United States & 0.14 & 0.10 & 0.09 \\
Romania & 0.08 & 0.09 & 0.13 \\
Morocco & 0.13 & 0.08 & 0.08 \\
Russia & 0.00 & 0.09 & 0.18 \\
No. establishments & 4,023 & 14,198 & 12,733 \\
No. workers & $2,399,994$ & $1,908,292$ & $1,362,878$ \\
\hline
\end{tabular}

The nationality variable is based on the most commonly occurring foreign nationality as defined in Appendix A. Nationalities shown are those with at least $0.1 \%$ of the workforce in any of the three time periods, ordered by their frequency over the whole sample period (1991-2006).

be foreign-owned and are more likely to be in the manufacturing sector. In terms of location, non-exporters are more likely to be in Eastern Germany and are further away from a border with another country.

The bottom panel of Table 2 compares the average characteristics of workers in establishments by their export status. Exporting establishments pay higher wages and their workers are slightly older and more experienced. Exporting establishments do not simply employ more skilled workers: they employ a larger proportion of basic manual workers but also a larger proportion of engineers, technicians and qualified business occupations. This may reflect the sectoral composition of exporting and non-exporting establishments, which we will control for in our regression analysis.

The penultimate pair of lines of Table 2 provide the first descriptive evidence that the proportion of foreign workers differs between exporting and non-exporting establishments. $8.6 \%$ of the workforce in establishments which export more than half their output are foreign, compared to only $4.1 \%$ in establishments which do not export. A similar pattern persists if we only consider foreign workers from non-Gastarbeiter countries. Of course, there might be other characteristics of exporting establishments which are correlated with their employment of foreigners. One possibility is that establishments 
Table 2: Characteristics of establishments and workers by exporting status, 19932008.

\begin{tabular}{|c|c|c|c|c|}
\hline & $\begin{array}{r}\text { Zero } \\
\text { exports }\end{array}$ & $\begin{array}{r}\text { Exports } \\
<10 \%\end{array}$ & $\begin{array}{c}\text { Exports } \\
10-50 \%\end{array}$ & $\begin{array}{r}\text { Exports } \\
>50 \%\end{array}$ \\
\hline \multicolumn{5}{|l|}{ Establishment characteristics } \\
\hline$\%$ of sales exported & 0.0 & 5.8 & 29.8 & 72.2 \\
\hline Average sales (€m, constant prices) & 18.1 & 37.3 & 91.4 & 229.6 \\
\hline Average employment & 59.4 & 123.4 & 314.2 & 666.1 \\
\hline$\%$ foreign-owned & 4.4 & 10.5 & 19.4 & 31.8 \\
\hline$\%$ in manufacturing & 32.2 & 59.3 & 79.0 & 80.5 \\
\hline$\%$ head office & 7.1 & 11.5 & 14.7 & 17.6 \\
\hline$\%$ independent establishment & 76.2 & 72.8 & 64.9 & 53.7 \\
\hline$\%$ in large city & 60.0 & 58.5 & 54.7 & 64.5 \\
\hline Average distance to border district $(\mathrm{km})^{\mathrm{a}}$ & 74.0 & 67.1 & 72.1 & 69.4 \\
\hline$\%$ in a border district & 14.7 & 20.4 & 17.0 & 18.8 \\
\hline \% in Eastern Germany & 44.2 & 35.1 & 27.3 & 21.6 \\
\hline \multicolumn{5}{|l|}{ Worker characteristics } \\
\hline Average daily wage ( $€$, constant prices) & 80.8 & 99.2 & 107.6 & 116.7 \\
\hline Average age (years) & 39.2 & 40.1 & 40.6 & 40.7 \\
\hline Average tenure (years) & 4.5 & 5.4 & 6.3 & 6.9 \\
\hline$\%$ basic manual occupation ${ }^{\mathrm{b}}$ & 15.0 & 24.7 & 33.7 & 29.7 \\
\hline$\%$ qualified manual occupation & 20.3 & 22.1 & 20.1 & 19.8 \\
\hline$\%$ engineers and technicians & 8.4 & 9.9 & 12.8 & 18.4 \\
\hline$\%$ basic service occupation & 13.8 & 10.5 & 8.2 & 6.7 \\
\hline$\%$ qualified service occupation & 3.7 & 0.4 & 0.3 & 0.3 \\
\hline$\%$ semi-professional & 0.5 & 0.3 & 0.2 & 0.2 \\
\hline$\%$ professional & 1.2 & 1.0 & 0.7 & 0.6 \\
\hline$\%$ basic business occupation & 12.3 & 5.7 & 3.2 & 2.7 \\
\hline$\%$ qualified business occupation & 20.3 & 21.4 & 17.5 & 17.9 \\
\hline$\%$ manager & 4.5 & 3.9 & 3.3 & 3.6 \\
\hline$\%$ foreign national (all) & 4.1 & 5.4 & 7.7 & 8.6 \\
\hline$\%$ foreign national (excluding Gastarbeiter) & 1.6 & 2.1 & 2.4 & 3.4 \\
\hline No. of establishment-years & 57,092 & 8,639 & 12,171 & 5,854 \\
\hline No. of establishments & 15,890 & 3,820 & 4,110 & 1,883 \\
\hline
\end{tabular}

${ }^{a}$ Straight-line distance to the centre of the nearest district which has a border with another country.

${ }^{\mathrm{b}}$ See Table B1 for a description of occupational codes used. 
Table 3: Workers' nationality by occupation and establishments' export status. The first row replicates the final row of Table 2. The remaining rows report the proportion of each occupational group which is foreign.

\begin{tabular}{lrrrrr}
\hline & $\begin{array}{r}\text { Zero } \\
\text { exports } \\
\text { \% foreign national (excluding Gastarbeiter) }\end{array}$ & $\begin{array}{r}\text { Exports } \\
<10 \%\end{array}$ & $\begin{array}{r}\text { Exports } \\
10-50 \%\end{array}$ & $\begin{array}{r}\text { Exports } \\
>50 \%\end{array}$ & $\begin{array}{r}\text { Ratio } \\
(4) /(1)\end{array}$ \\
& 1.6 & 2.1 & 2.4 & 3.4 & 2.1 \\
\% foreign nationals in occupation: & & & & & \\
basic manual occupation & & & & & \\
qualified manual occupation & 2.8 & 2.9 & 2.7 & 3.1 & 1.1 \\
engineers and technicians & 1.3 & 1.6 & 1.6 & 1.8 & 1.4 \\
basic service occupation & 1.1 & 1.3 & 1.5 & 2.2 & 2.0 \\
qualified service occupation & 2.0 & 2.1 & 2.3 & 2.8 & 1.4 \\
semi-professional & 1.4 & 1.9 & 1.3 & 1.9 & 1.4 \\
professional & 1.9 & 2.0 & 3.3 & 3.9 & 2.1 \\
basic business occupation & 1.6 & 1.4 & 2.2 & 2.5 & 1.6 \\
qualified business occupation & 1.1 & 1.2 & 1.6 & 2.9 & 2.6 \\
manager & 0.8 & 0.9 & 1.5 & 2.4 & 3.0 \\
\hline
\end{tabular}

are located in locations with lower exporting costs, and those locations also have higher proportions of foreign workers, for example cities or districts close to foreign borders. In our regression analysis we therefore control for local area effects.

Another explanation for the fact that exporting establishments employ more foreign workers might be that foreign workers are concentrated in industries and occupations which are export intensive. For example, foreign workers in Germany might be concentrated in low-skill manual occupations which are intensively required by exporting establishments. This might be particularly the case for Gastarbeiter. In our regression analysis we therefore also consider the occupational structure of employment in the establishment and foreign workers from non-Gastarbeiter countries.

More evidence that foreign workers lower exporting transaction costs comes from examining the proportion of foreign workers by occupation. Because we have data on individual workers, we can identify whether foreign workers are in senior occupational positions, and we would expect that those workers will have more of an effect on exporting than those working in production or in less-skilled occupations. This is illustrated in Table 3, which shows that the increase in the share of foreign workers in exporting establishments is greater for workers in managerial, business and engineering occupations. For example, $3.9 \%$ of managers in export-intensive establishments are foreign, compared to $1.1 \%$ of managers in non-exporting establishments. The ratio of these shares (3.5) is much higher than the equivalent ratio for manual (1.1) and service occupations (1.4). 


\section{Methods and hypotheses}

In this section we describe the methods we use to examine whether the proportion of foreign workers in an establishment has a causal impact on the probability of entering export markets.

Our basic specification is a linear probability model which relates the exporting status of establishment $j$ in year $t$ to the proportion of workers in the establishment who have foreign nationality, on June 30th in the previous year. This is written:

$$
\operatorname{Pr}\left(y_{j t}=1\right)=\beta_{0}+\beta_{F} \bar{F}_{j t-1}+\beta_{\mathbf{x}} \mathbf{x}_{j t}+a_{k t}+u_{j t},
$$

where $y_{j t}$ is a dummy for whether or not an establishment exports, $\bar{F}_{j t-1}$ is our measure of foreign workers, $\mathbf{x}_{j t}$ is a vector of controls, and $a_{k t}$ and $u_{j t}$ are unobservables.

Define $F_{i}$ as a dummy variable recording whether worker $i$ is foreign, then

$$
N_{j t}^{F} \equiv \sum_{i \in J(i, t)} F_{i}
$$

is the number of foreign workers in establishment $j$ at time $t$, where $J(i, t)=j$ is the function that maps worker $i$ at time $t$ to establishment $j$. Our measure of foreign employment is the lagged share of foreign workers in establishment $j$ :

$$
\bar{F}_{j t-1} \equiv \frac{N_{j t-1}^{F}}{N_{j t-1}}
$$

As discussed in Sections 1 and 2, this variable may be endogenous. OLS estimates of $\beta_{F}$ will be biased if $\bar{F}_{j t-1}$ is correlated with either $a_{k t}$ or $u_{j t}$ or both.

The first source of endogeneity is the standard unobserved heterogeneity argument. Specifically, $a_{k t}$ represents factors specific to district $k$ at time $t$ which increase export propensity. For example, establishments with more foreign workers might be located in districts with lower transaction costs, and these establishments hire from the local labour market. Similarly, $u_{j t}$ represents establishment-specific time-varying factors which increase the export propensity. For example, some establishments have higher productivity and these establishments may also be more likely to hire foreign workers.

The second source of endogeneity arises because of reverse causality, whereby foreign 
workers work for establishments which export their output. This could be because establishments that have a high propensity to export choose to hire foreign workers, or because foreign workers choose to work for these establishments.

To deal with the district-level endogeneity captured by the $a_{k t}$ term, we include district fixed-effects or a set of characteristics such as distance to border, whether bordering another country, urbanisation etc. Implicitly one is assuming that $a_{k t}=a_{k}$. If one suspects that $a_{k t}$ varies over time, one can include time-district dummies; this we also do.

To minimise the establishment-level endogeneity caused by the correlation between the $u_{j t}$ term and $\bar{F}_{j t-1}$, we include a set of establishment-level controls relating to foreign ownership, legal status, size, whether the establishment is part of a larger firm, and industry. In addition, $u_{j t}$ can include the quality of a establishment's workforce. If foreign workers have systematically different skill-levels for example, then there may be an additional effect of having a foreign workforce. Because we have linked data we can also include measures of the education and occupation level of the establishment's workforce. ${ }^{14}$ This controls for any difference in education and skill level between foreign and German workers.

However, even after controlling for observable establishment-level characteristics, there may be other characteristics which increase the establishment's export propensity but which are not observed in the data. We therefore require an instrument which exogenously affects $\bar{F}_{j t-1}$ but which is uncorrelated with $u_{j t}$. It cannot, therefore, have a direct influence on exporting behaviour. Our preferred instrument is the proportion of foreign workers in district $k$ who do not themselves work in establishment $j .{ }^{15}$ The instrument for $\bar{F}_{j t-1}$ is therefore

$$
z_{j t-1} \equiv \frac{N_{k t-1}^{F}-N_{j t-1}^{F}}{N_{k t-1}-N_{j t-1}}
$$

where $N_{k t-1}^{F}$ is the number of foreign workers in district $k$ at $t-1$. Note that $z_{j t-1}$ varies at the establishment level (not just the district level) because it excludes workers from establishment $j$. To construct the instrument we use the entire employment statistics register collapsed down to the district level (Kreis) ${ }^{16}$ If establishments hire workers only

\footnotetext{
${ }^{14}$ These are also measured on June 30th in the year before the exporting information is recorded.

${ }^{15}$ This instrument is the same as one of those used by Hiller (2013).

${ }^{16}$ See Figure 2.
} 
from other establishments in their district then this instrument will be highly correlated

with $\bar{F}_{j t-1}$, and should have a coefficient of approximately one, because an increase in the share of foreigners in other establishments in the district should be associated with an equal increase in the share of foreigners in the establishment. The extent to which the coefficient differs from unity will give us some indication of the extent to which establishments do hire mainly from the local district. We also consider a second potential instrument, the proportion of foreign workers in the industry of establishment $j$, excluding establishment $j$ itself.

An alternative method for dealing with unobserved establishment-level factors would be to allow for establishment fixed-effects, as used for example by Hiller (2013). However, in our sample we observe little time variation either in the share of foreigners within the establishment or in the exporting outcome (as is well known, the decision to export is highly serially correlated). We also note that there is clear evidence of measurement error in the nationality variable (see Appendix A), which may cause large attenuation bias in fixed-effects estimates (Wooldridge, 2010, p.365). For these reasons, we rely on 2SLS methods to deal with the endogeneity problem.

\section{Results}

We start with the basic linear probability model given in Equation (1), and then estimate a number of alternative specifications to establish the robustness of the relationship, and to investigate the reasons for the relationship. The dependent variable is an indicator which takes the value 1 if an establishment exports any of its sales in year $t$, and 0 otherwise. The key explanatory variable is $\bar{F}_{j t-1}$, the proportion of foreign workers in the establishment in the year prior to the exporting information. Our base definition of foreign worker excludes worker from Gastarbeiter countries. Table 4 reports our first set of results.

The sample mean of $\bar{F}_{j t-1}$ across all observations in the sample is 0.019 with a standard deviation of $0.065 .{ }^{17}$ So, the raw estimate in column (1) implies that a one standard deviation increase in the proportion of foreign workers in an establishment increases the probability of exporting by $0.065 \times 0.460$, which is about 3 percentage points. In column

\footnotetext{
${ }^{17}$ This is a much smaller proportion than indicated in Table 1 because we have excluded foreign workers from Gastarbeiter countries.
} 
Table 4: OLS estimates of (1). The dependent variable is a dummy indicating whether the establishment exports in year $t, \bar{F}_{j t-1}$ is the proportion of workers in the establishment who are foreign, excluding workers from Gastarbeiter countries.

\begin{tabular}{|c|c|c|c|c|c|}
\hline & $\begin{array}{c}(1) \\
\text { Raw effect }\end{array}$ & $\begin{array}{c}(2) \\
\text { Base model }\end{array}$ & $\begin{array}{c}(3) \\
\text { District FE }\end{array}$ & $\begin{array}{c}(4) \\
\text { District- } \\
\text { year FE }\end{array}$ & $\begin{array}{c}(5) \\
\text { Base including } \\
\text { Gastarbeiter }\end{array}$ \\
\hline $\begin{array}{l}\bar{F}_{j t-1} \\
\bar{F}_{j t-1}^{G} \\
\text { (Gastarbeiter) }\end{array}$ & $\begin{array}{l}0.460^{* * *} \\
(0.054)\end{array}$ & $\begin{array}{l}0.226^{* * *} \\
(0.041)\end{array}$ & $\begin{array}{l}0.197^{* * *} \\
(0.040)\end{array}$ & $\begin{array}{l}0.214^{* * *} \\
(0.042)\end{array}$ & $\begin{array}{c}0.226^{* * *} \\
(0.041) \\
0.016 \\
(0.027)\end{array}$ \\
\hline Foreign-owned & & $\begin{array}{l}0.161^{* * *} \\
(0.011)\end{array}$ & $\begin{array}{l}0.160^{* * *} \\
(0.011)\end{array}$ & $\begin{array}{l}0.163^{* * *} \\
(0.011)\end{array}$ & $\begin{array}{l}0.161^{* * *} \\
(0.011)\end{array}$ \\
\hline Distance to border $(\mathrm{km})$ & & $\begin{array}{c}-0.019^{* * *} \\
(0.007)\end{array}$ & & & $\begin{array}{l}-0.019^{* * *} \\
(0.007)\end{array}$ \\
\hline Border district & & $\begin{array}{l}0.050^{* * *} \\
(0.010)\end{array}$ & & & $\begin{array}{l}0.051^{* * *} \\
(0.010)\end{array}$ \\
\hline Eastern Germany & & $\begin{array}{c}-0.102^{* * *} \\
(0.006)\end{array}$ & & & $\begin{array}{c}-0.102^{* * *} \\
(0.006)\end{array}$ \\
\hline Firm organisation $(2)^{\mathrm{a}}$ & & Yes & Yes & Yes & Yes \\
\hline Urbanicity $(9)^{\mathrm{b}}$ & & Yes & Yes & Yes & Yes \\
\hline Industry (10) & & Yes & Yes & Yes & Yes \\
\hline Size classes (9) & & Yes & Yes & Yes & Yes \\
\hline Year $(15)$ & & Yes & Yes & Yes & Yes \\
\hline Occupation $(9)^{\mathrm{c}}$ & & Yes & Yes & Yes & Yes \\
\hline District (439) & & No & Yes & No & No \\
\hline District-year (6212) & & No & No & Yes & No \\
\hline$R^{2}$ & 0.004 & 0.345 & 0.369 & 0.402 & 0.345 \\
\hline Number of obs. & 83,756 & 83,756 & 83,756 & 83,756 & 83,756 \\
\hline Number of establishments & 20,700 & 20,700 & 20,700 & 20,700 & 20,700 \\
\hline \multicolumn{6}{|c|}{$\begin{array}{l}\text { Standard-errors in parentheses are clustered at the establishment level. }{ }^{* * *} \text { indicates } p<0.01,{ }^{* *} \\
\text { indicates } 0.01 \leq p<0.05 \text { and }{ }^{*} \text { indicates } 0.05 \leq p<0.1 \text {. } \\
\text { a Establishments are categorised as being an independent company, part of a larger firm, or a head } \\
\text { office. } \\
\text { b Urbanicity dummies control for the population density of the establishment's location. } \\
\text { c Occupation controls consist of the proportion of the establishment's workforce in each 1-digit } \\
\text { occupation category, as shown in the bottom panel of Table } 2 \text {. }\end{array}$} \\
\hline
\end{tabular}

(2) we report our base model which controls for a rich set of establishment and worker characteristics. Their inclusion reduces the effect of foreign workers on exports, but the estimate is still highly significant, and suggests that a one standard-deviation increase in the proportion of foreign workers in the establishment increases export propensity by 1.5 percentage points. Column (2) also shows that export propensity is significantly related in the expected way to foreign-ownership, the distance of the establishment to the German border, and whether the establishment is located in a district which is at the German border. Establishments in Eastern Germany are also significantly less likely to export. We also control for the population density of the district in which the establishment is located, industry, employment size, time and the occupational structure of the establishment.

In columns (3) and (4) we show that the inclusion of district fixed-effects or district- 
year fixed effects makes very little difference to the size of the estimated effect, demonstrating that the result is not driven by the correlation between $a_{k t}$ and $\bar{F}_{j t-1}$ in Equation (1), conditional on having controlled for location effects. In column (5) we show that the inclusion of a measure of foreign workers from Gastarbeiter countries within the establishment has no additional effect, and shows that export propensity is not affected by workers from these countries.

There might be a concern that the relationship is strongly affected by the relationship between establishment size, exporting and nationality: large establishments export, and large establishments almost all employ some foreign workers. Our base model includes 9 size-class dummy variables, but a robustness check with a dummy for every value of establishment employment - that is, 2,432 dummies - yields a coefficient of $0.234(0.041)$. Our results are also robust if we exclude very large establishments: removing those which employ more than 200 workers (approximately 10\% of establishments) increases the estimated effect very slightly to 0.243 (0.041). We also note that a Probit estimate of the probability of exporting is very similar to the linear probability model we use, with an average marginal effect of $0.226(0.036)$.

We now consider the possible endogeneity of $\bar{F}_{j t-1}$. In Table 5 we report our basic 2SLS estimates. The first-stage estimates in column (1) show that the regression of $\bar{F}_{j t-1}$ on the proportion of foreign workers in the district (excluding those working in the establishment itself) delivers an estimated coefficient of 0.78 (0.072). A coefficient close to unity is what we would expect if establishments mainly hire workers from other establishments within the local district. The use of this instrument increases the estimated effect of foreign workers on exporting fivefold, so that a one-standard deviation increase in the proportion of foreign workers in the establishment is now predicted to increase the probability of exporting by $0.065 \times 1.150$, approximately 7.5 percentage points. However, the precision of the estimate is reduced considerably, and we cannot rule out effects with a 95\% confidence interval ranging from 1.5-13 percentage points. The inclusion of a measure of employment from Gastarbeiter countries makes very little difference to the result.

A second potential instrument is the proportion of foreign workers in the same industry as establishment $j$, excluding those in establishment $j$ itself. Using both the district and the industry instruments the estimated effect of foreign workers is almost identical 
Table 5: 2SLS estimates of (1), where the proportion of foreigners in the establishment is instrumented by the proportion in the district.

\begin{tabular}{|c|c|c|c|c|}
\hline \multirow{3}{*}{$\begin{array}{l}z_{j t-1} \\
\text { (Prop of foreign workers in district) }\end{array}$} & \multicolumn{2}{|c|}{ (1) Base model } & \multicolumn{2}{|c|}{ (2) Including Gastarbeiter } \\
\hline & $\begin{array}{l}\text { First stage } \\
\bar{F}_{j t-1}\end{array}$ & $\begin{array}{l}\text { Second stage } \\
\operatorname{Pr}(\text { Exporter })\end{array}$ & $\begin{array}{l}\text { First stage } \\
\bar{F}_{j t-1}\end{array}$ & $\begin{array}{l}\text { Second stage } \\
\operatorname{Pr}(\text { Exporter })\end{array}$ \\
\hline & $\begin{array}{c}0.780^{* *} \\
(0.072)\end{array}$ & & $\begin{array}{r}0.786^{*} \\
(0.073)\end{array}$ & \\
\hline $\bar{F}_{j t-1}$ & & $\begin{array}{l}1.150^{* *} \\
(0.463)\end{array}$ & & $\begin{array}{l}1.061^{* *} \\
(0.449)\end{array}$ \\
\hline $\begin{array}{l}\bar{F}_{j t-1}^{G}{ }^{\mathrm{a}} \\
(\text { Gastarbeiter })\end{array}$ & & & & $\begin{array}{c}0.169 \\
(0.190)\end{array}$ \\
\hline $\begin{array}{l}R^{2} \\
F \text {-statistic } \\
p \text {-value }\end{array}$ & $\begin{array}{c}0.079 \\
118.20 \\
{[0.000]}\end{array}$ & & $\begin{array}{r}0.079 \\
58.676 \\
{[0.000]}\end{array}$ & \\
\hline $\begin{array}{l}\text { Exogeneity test } F \text {-statistic } \\
p \text {-value }\end{array}$ & & $\begin{array}{c}4.124 \\
{[0.043]}\end{array}$ & & $\begin{array}{c}2.201 \\
{[0.112]}\end{array}$ \\
\hline $\begin{array}{l}\text { Number of observations } \\
\text { Number of establishments }\end{array}$ & & $\begin{array}{l}756 \\
700\end{array}$ & & $\begin{array}{l}756 \\
700\end{array}$ \\
\hline
\end{tabular}

Standard errors in parentheses are clustered at the district level. Regressions include the same set of controls used in Table 4.

a The proportion of foreign workers from Gastarbeiter countries is also instrumented by the proportion of those workers in the district. First-stage results for this instrument are not reported.

(1.094 with a cluster-robust standard error of 0.501), so our conclusion is essentially unchanged. ${ }^{18}$ Neither the Sargan nor the Basmann tests of overidentification reject the null, with $p$-values of 0.655 .

Standard omitted-variables type arguments suggest that the OLS estimates are biased upwards if we think that unobserved export propensity $\left(u_{j t}\right)$ is positively correlated with the stock of foreign workers. The fact that the 2SLS estimates are larger than the corresponding OLS estimates is therefore unexpected. But there are at least two wellknown reasons why we might get this result. The first is that the causal impact of foreign workers on export behaviour is heterogeneous, rather than homogeneous as in (1). In this case, the IV estimates are estimates of the foreign-worker effect for those establishments whose behaviour is affected by the instrument (the proportion of foreign workers in the local labour market). If we think that those establishments who benefit most from hiring foreign workers are those who take advantage of foreign workers in the local labour market, our result is intuitive. The second explanation is that measurement error in $\bar{F}_{j t-1}$ causes attenuation bias in the OLS estimates. It is very unlikely that the instrument is uncorrelated with the errors that individual establishments make when reporting their workers' nationality, and so the instrument corrects for this measurement

\footnotetext{
${ }^{18}$ When using both district and industry instuments we allow for clustering at both levels, as recommended by Cameron and Miller (2015).
} 
error.

For these 2SLS results to be plausible, we require that the number of foreign workers in the district (outside the establishment) is independent of establishments' unobserved exporting propensity, $u_{j t}$, and independent of the unobserved district exporting propensity $a_{k t}$. Since our model includes detailed controls for $a_{k t}$ (e.g. distance to border) we can rule out the problem that migrants choose to locate in districts with low transaction costs, ceteris paribus. Our main concern is therefore whether $\operatorname{Cov}\left(z_{j t-1}, u_{j t}\right)=0$. It seems possible that this will not be the case if establishments with high exporting propensity choose to locate in districts with a high proportion of foreign workers. Since at least Marshall (1920) economists have argued that firms may cluster together, perhaps because of the availability of a skilled workforce.

To test whether an establishment's location decision is influenced by the pre-existing stock of migrants in a district, we estimate a model of establishments' location choices. We take our regression sample of establishments and record the year in which they started production. ${ }^{19}$ We classify establishments according to their exporting propensity, measured as the fraction of times they are observed to export. We then calculate the share of "new" exporting establishments in each district and regress this share on the proportion of foreign workers in each district. ${ }^{20}$ We include a full set of district-level controls based on the same variables as in the outcome equation. We also include district-level averages of all other variables. Results are shown in column (1) of Table 6, and show that the proportion of existing foreigners in a district has no impact on the proportion of new exporters in a district. Nor does there appear to be any "clustering" of new exporters in districts which have a larger fraction of pre-existing exporters.

A second reason why $\operatorname{Cov}\left(z_{j t-1}, u_{j t}\right)$ might not be zero is that foreign workers choose to locate in districts which already have a larger fraction of exporting establishments (after conditioning on those district characteristics such as distance to the border which we control for). We therefore also estimate a model of migrants' location choices. We calculate the number of migrants in each district and in each year who are "new" in the social security statistics, a measure of the location choices of new migrants. ${ }^{21}$ We

\footnotetext{
${ }^{19}$ The year in which the establishment started production is censored at 1990 . We therefore use only those establishments which started after 1990.

${ }^{20} \mathrm{New}$ is defined as having entered within the past three years. We do this across all years because of the relatively small number of exporting establishments which enter production over the sample period.

${ }^{21}$ This will not be an exact measure because migrants may arrive some time before they appear in the social security statistics.
} 
Table 6: Location decisions of new exporting establishments and new migrants.

\begin{tabular}{lcc}
\hline & $\begin{array}{c}(1) \\
\text { Proportion of new } \\
\text { exporters in district }\end{array}$ & $\begin{array}{c}(2) \\
\text { Proportion of new } \\
\text { migrants in district }\end{array}$ \\
\hline Proportion of existing foreigners & 0.052 & $0.043^{* *}$ \\
& $(0.046)$ & $(0.018)$ \\
Proportion of existing exporters & -0.002 & -0.0004 \\
& $(0.002)$ & $(0.003)$ \\
$R^{2}$ & 0.269 & 0.477 \\
Number of obs. & 415 & 5,868 \\
Number of districts & 415 & 413 \\
\hline
\end{tabular}

OLS estimates. Standard errors in parentheses are heteroskedasticity-robust in column (1) and are clustered at the district level in column (2). Regressions include the same set of controls used in Table 4.

then regress the share of new foreigners on the proportion of existing exporters and existing foreigners in each district. Results are in column (2) of Table 6, and show that the proportion of existing exporting establishments in a district has no impact on the location decisions of migrants. In this case, however, there is the well-known effect that migrants choose to locate in districts with a higher proportion of existing foreigners, but this does not threaten the exogeneity of the instrument.

Our results thus far indicate that establishments with more foreign workers are significantly more likely to export. We now investigate whether, as seems likely, foreign workers in more senior occupations are responsible for this effect. In particular, we test whether the proportion of foreign workers in the establishment who are managers (see Appendix B for definitions) has an additional effect on the export propensity. Results are shown in Table 7 .

The results in column (1) indicate that, holding the overall proportion of foreign workers in an establishment constant, increasing the share of foreign managers has a significant additional effect on the likelihood of exporting. On average, establishments which have any managers have 9 managers, of which less than $2 \%$ are foreign, because the great majority of establishments have no foreign managers. Hiring one foreign manager therefore, on average, increases the share of managers who are foreign by about $1 / 9$, which increases export propensity by about 1 percentage point $(1 / 9 \times 0.103)$. As before, these results are much larger when we instrument although imprecisely estimated. We find similar results when we use the nationality of the highest-paid worker in the establishment, shown in columns (3) and (4). Establishments whose highest-paid worker is foreign are 10 points more likely to export, and the effect of the highest-paid worker in 
Table 7: The probability of exporting as a function of the proportion of foreign workers by occupation or rank within the establishment.

\begin{tabular}{|c|c|c|c|c|}
\hline & $\begin{array}{c}(1) \\
\text { OLS }\end{array}$ & $\begin{array}{c}(2) \\
2 \mathrm{SLS}\end{array}$ & $\begin{array}{c}(3) \\
\text { OLS }\end{array}$ & $\begin{array}{c}(4) \\
2 \mathrm{SLS}\end{array}$ \\
\hline $\begin{array}{l}\bar{F}_{j t-1} \\
(\text { All) } \\
\bar{F}_{j t-1} \\
\text { (managers, occupation } 10 \text { ) }\end{array}$ & $\begin{array}{l}0.267^{* * *} \\
(0.102) \\
0.103^{* *} \\
(0.046)\end{array}$ & $\begin{array}{c}0.064 \\
(0.770) \\
2.248^{* *} \\
(1.134)\end{array}$ & $\begin{array}{l}0.137^{* * *} \\
(0.044)\end{array}$ & $\begin{array}{r}-0.618 \\
(1.088)\end{array}$ \\
\hline $\begin{array}{l}\text { Highest-paid worker } \\
\text { is foreign }\end{array}$ & & & $\begin{array}{l}0.104^{* * *} \\
(0.023)\end{array}$ & $\begin{array}{c}2.311 \\
(1.415)\end{array}$ \\
\hline $\begin{array}{l}\text { Exogeneity test } F \text {-statistic } \\
p \text {-value }\end{array}$ & & $\begin{array}{l}4.215 \\
{[0.015]}\end{array}$ & & $\begin{array}{c}2.813 \\
{[0.061]}\end{array}$ \\
\hline$R^{2}$ & 0.391 & & 0.345 & \\
\hline $\begin{array}{l}\text { Number of obs. } \\
\text { Number of establishments }\end{array}$ & \multicolumn{2}{|c|}{$\begin{array}{c}36,313 \\
9,400\end{array}$} & \multicolumn{2}{|c|}{83,386} \\
\hline
\end{tabular}

The explanatory variables in columns (1) and (2) are the the same as in the base model with the addition of a measure of the proportion of managers in the establishment who are foreign. Establishments with no workers classified as managers are not in the sample. The explanatory variables in columns (3) and (4) are the same as in the base model with the addition of a dummy variable indicating whether the highest paid worker in the establishment is foreign, excluding Gastarbeiter. Standard errors in parentheses are clustered at the establishment level for OLS regressions and at district level for 2SLS regressions.

the IV regression is again much larger.

We now turn to the question of whether foreign workers' effect on exporting behaviour is driven by specific country links. A typical gravity model would impose this by assumption, by regressing exports from a firm to a particular destination country on the number (or share) of foreign workers from that country. This excludes the possibility that (for example) foreign workers from country $j$ may lower transaction costs between the host country $i$ and a third country $k$. Because we do not have detailed export destination information, our base model merely shows that foreign workers have an effect on all export destinations. Although the data do not record the precise destination of exports, from 1998 onwards we do know whether establishments export to the European Monetary Union (EMU), and from 2004 onwards we know whether establishments export to the accession countries of the European Union.

The OLS results in column (1) of Table 8 show a clear pattern: for exports to EMU countries, foreign workers from EMU countries have a large significant effect (twice as large as in the base model), while foreign workers from NMS countries and foreign workers from other countries have no additional effect. As in the base model, when we instrument by the relevant stocks of foreign workers in the district in column (2) the foreign-worker effect becomes larger, although note that this estimate is quite imprecise. 
Table 8: The probability of exporting to a particular region as a function of the proportion of foreign workers from that region.

\begin{tabular}{|c|c|c|c|c|}
\hline & \multirow{2}{*}{\multicolumn{2}{|c|}{$\begin{array}{l}(1) \\
\text { Exports to EMU }\end{array}$}} & \multirow{2}{*}{\multicolumn{2}{|c|}{$\begin{array}{l}(3) \\
\text { Exports to } \mathrm{NMS}^{\mathrm{b}}\end{array}$}} \\
\hline & & & & \\
\hline & OLS & 2SLS & OLS & 2SLS \\
\hline $\bar{F}_{j t-1}$ (EMU countries) & $\begin{array}{l}0.478^{* * *} \\
(0.079)\end{array}$ & $\begin{array}{l}1.840^{* * *} \\
(1.086)\end{array}$ & $\begin{array}{c}0.044 \\
(0.062)\end{array}$ & $\begin{array}{c}-0.987^{* *} \\
(0.486)\end{array}$ \\
\hline $\bar{F}_{j t-1}$ (NMS countries) & $\begin{array}{c}-0.030 \\
(0.057)\end{array}$ & $\begin{array}{c}-1.707 \\
(2.415)\end{array}$ & $\begin{array}{c}0.030 \\
(0.041)\end{array}$ & $\begin{array}{c}3.312 \\
(2.840)\end{array}$ \\
\hline $\bar{F}_{j t-1}$ (Other foreign countries) & $\begin{array}{c}0.069 \\
(0.053)\end{array}$ & $\begin{array}{r}-0.087 \\
(1.234)\end{array}$ & $\begin{array}{r}-0.076 \\
(0.039)\end{array}$ & $\begin{array}{r}-0.645 \\
(1.157)\end{array}$ \\
\hline $\begin{array}{l}\text { Years }^{\mathrm{c}} \\
\text { Exogeneity test } F \text {-statistic } \\
p \text {-value }\end{array}$ & $1998-2007$ & $\begin{array}{l}1998-2007 \\
4.335 \\
{[0.005]}\end{array}$ & $2004-2007$ & $\begin{array}{l}2004-2007 \\
6.619 \\
{[0.000]}\end{array}$ \\
\hline$R^{2}$ & 0.336 & & 0.236 & \\
\hline Number of observations & 68,478 & 68,478 & 30,529 & 30,529 \\
\hline Number of establishments & 18,845 & 18,845 & 11,926 & 11,926 \\
\hline
\end{tabular}

Standard errors in parentheses are clustered at the establishment level for OLS regressions and at district level for 2SLS regressions. Regressions include the same set of controls used in Table 4.

${ }^{a}$ EMU countries are those countries which are members of the European Monetary Union at $t$. At the beginning of the sample period these countries were: Austria, Belgium, Finland, France, Greece, Ireland, Italy, Luxembourg, the Netherlands, Portugal and Spain.

b NMS are New Member States which joined the European Union in 2004: Cyprus, Czech Republic, Estonia, Hungary, Latvia, Lithuania, Malta, Poland, Slovakia and Slovenia.

c The survey only records exports to EMU countries from 1998 onwards, and exports to NMS countries from 2004 onwards. The base model estimated on these sub-periods yields almost identical estimates of the overall effect of $\bar{F}_{j t-1}$ on the probability of exporting to any destination. Results are available on request. 
Table 9: Alternative specifications.

\begin{tabular}{lcccc}
\hline & $(1)$ & $(2)$ & $(3)$ & $(4)$ \\
& $\begin{array}{c}\text { Log } \\
\text { exports }^{\mathrm{a}}\end{array}$ & $\begin{array}{c}\text { Non- } \\
\text { linear }\end{array}$ & $\begin{array}{c}\text { Western } \\
\text { Germany }\end{array}$ & $\begin{array}{c}\text { Eastern } \\
\text { Germany }\end{array}$ \\
\hline $\bar{F}_{j t-1}$ & $1.196^{* * *}$ & & $0.213^{* * *}$ & $0.264^{* *}$ \\
& $(0.272)$ & & $(0.043)$ & $(0.113)$ \\
$\bar{F}_{j t-1}$ (quartile 1) $^{\mathrm{b}}$ & & $0.085^{* * *}$ & & \\
$\bar{F}_{j t-1}$ (quartile 2) & & $(0.011)$ & \\
$\bar{F}_{j t-1}$ (quartile 3) & & $0.119^{* * *}$ & & \\
& & $(0.010)$ & \\
$\bar{F}_{j t-1}$ (quartile 4) & & $0.099^{* * *}$ & & \\
& & $(0.010)$ & & \\
$R^{2}$ & & $0.080^{* * *}$ & & \\
Number of observations & 24,478 & $(0.010)$ & & \\
Number of establishments & 7,102 & 20,700 & 13,172 & 7,691 \\
\hline
\end{tabular}

Standard errors in parentheses are clustered at the establishment level. All regressions include the same set of controls used in the base model in Table 4.

a Model includes only those establishments which report positive exports.

${ }^{\text {b }}$ Quartiles of $\bar{F}_{j t-1}$ for those establishments with $\bar{F}_{j t-1}>0$ i.e. those establishments with any foreign workers. The $25 \mathrm{th}, 50 \mathrm{th}$ and 75 th percentiles are $1.0 \%, 2.1 \%$ and $4.6 \%$ respectively.

${ }^{\mathrm{c}}$ Proportion of establishment employment which is foreign and who first appeared in the social security statistics less than 5 years earlier.

Nevertheless, we still find a significant impact of EMU foreign workers on EMU exports, and no significant effect of other foreign workers. This lends support to the gravity-model approach in which trade between two countries is facilitated by the migration of workers between those two countries, rather than by foreign workers in general, as might be the case if foreign workers were generally more productive. The results for NMS exports are less clear-cut. The OLS results in column (3) do not provide any evidence of an export promotion effect of workers from either NMS or EU countries. In addition, 2SLS results in column (4) are too imprecise to draw any firm conclusions, although we note that the coefficient on NMS workers becomes much larger, in contrast to the coefficient on EMU workers and foreign workers from other countries.

Table 9 reports a number of additional results which test the robustness of our findings. In column (1) we test whether there is also a relationship between the share of foreign workers and total export volume for those establishments with positive exports. This model is more consistent with a firm-level gravity model. The estimated elasticity is 1.2 with a standard error of 0.27 .

In column (2) we examine whether the constant proportional effect of foreign workers imposed by the base model is appropriate. Theoretically, it seems possible that the effect of foreign workers on exports is non-proportional. For example, Gould (1994, 
p.307) assumes that information about the foreign market which foreign workers bring with them decreases transactions costs at a declining rate. ${ }^{22}$ To test proportionality we create dummies which separately identify establishments with different proportions of foreign workers, defined by the $25 \mathrm{th}, 50 \mathrm{th}$ and 75 th percentiles of the distribution of $\bar{F}_{j t-1}$. The results clearly reject a constant proportional effect. All establishments with foreign workers are significantly more likely to export, but the effect is as large for establishments in the first quartile (0.085) as those in the fourth quartile (0.080). Thus, the positive effect on exporting comes primarily from having any foreign workers rather than an increasing share.

In the remaining columns of Table 9 we consider whether there is any evidence that the effect of foreign workers on exporting behaviour is related to the strength of ties with the home country. We know that those migrants in the former East Germany are likely to be more recent arrivals who have stronger ties to their home country. The foreign worker effect is slightly larger for establishments in Eastern Germany. Excluding establishments in Berlin from the Eastern German sample increases the effect further to $0.303(0.149)$. This is consistent with the hypothesis that more recent migrants have stronger ties, but for stronger evidence we need to consider the export effect by the length of time a foreign worker has been in Germany. ${ }^{23}$

\section{Conclusion}

This paper provides new evidence for Germany which shows that establishment-level exporting heterogeneity is partly explained by the types of workers employed by those establishments. Specifically, establishments which employ a higher proportion of foreign workers are significantly more likely to export their output. This evidence is consistent with a number of country-level studies which show a link between bilateral export flows and stocks of migrants, and furthermore provides a clear mechanism for this effect. Germany provides a particularly important test-case for this relationship, since it represents a country which has both a large stock of foreign workers and enormous export volumes.

We have shown that the relationship which exists in the raw data is not wholly due to the industrial, occupational or (most importantly) geographical concentration of

\footnotetext{
${ }^{22}$ Even if each foreign worker offers a small fixed independent probability to break into a foreign market, then this implies a declining effect from hiring additional foreign workers.

${ }^{23}$ Unfortunately, the social security statistics do not record the year of arrival for foreign workers.
} 
foreign workers. Even within narrowly defined districts, a higher share of foreign workers is significantly associated with a higher probability of exporting. Thus, the effect is not driven by the co-location of foreign workers and establishments in districts with low exporting costs. This effect is not driven by workers from Gastarbeiter countries, and the effect is significant for workers who are more likely to play a role within the establishment in facilitating exporting decisions (i.e. managers), over and above the effect from the total foreign workforce. Even more strikingly, the relationship is also stronger when we consider exports to specific regions and workers from those regions within establishments, which supports the idea that foreign workers lower trade costs between their own origin and host countries (as would be suggested by a gravity model), rather than between countries more generally.

The OLS results provide an estimate of the causal impact of foreign workers on exporting decisions if hiring decisions are independent of export propensity. However, if there are unobserved factors which determine both export propensity and hiring policy, then an instrumental variable strategy is required. We use the pre-existing stock of foreign workers in the local district (outside the establishment) as an instrument. In support of our 2SLS strategy, we find no evidence, ceteris paribus that exporting establishments choose to locate in districts with pre-existing large stocks of foreign workers, nor that migrants choose to locate in districts with a higher proportion of exporting establishments. In almost every case our 2SLS estimates are significantly larger than the corresponding OLS estimates, which is suggestive of a varying treatment effect of hiring foreign workers, or the fact that foreign nationality is recorded with measurement error. 


\section{References}

Anderson, J. and van Wincoop, E. (2004), "Trade costs", Journal of Economic Literature 42(3), 691-751.

Bender, S., Haas, A. and Klose, C. (2000), "The IAB employment subsample 19751999”, Schmollers Jahrbuch 120(4), 649-662.

Bernard, A. B., Jensen, J. B., Redding, S. J. and Schott, P. K. (2007), "Firms in international trade", The Journal of Economic Perspectives 21(3), 105-130.

Bernard, A. and Jensen, B. (2004), "Why some firms export", The Review of Economics and Statistics 86(2), 561-569.

Cameron, A. C. and Miller, D. L. (2015), "A practitioners guide to cluster-robust inference", Journal of Human Resources 50(2), 317-372.

Egger, P., Ehrlich, M. and Nelson, D. (2012), "Migration and trade", The World Economy 35(2), 216-241.

Fischer, G., Janik, F., Müller, D. and Schmucker, A. (2009), "The IAB Establishment Panel — things users should know", Schmollers Jahrbuch 129(1), 133-148.

Frankel, J. (1997), Regional Trading Blocs in the World Economic System, Washington: Peterson Institute for International Economics.

Genc, M., Gheasi, M. and Nijkam, P. (2011), "The impact of immigration on international trade: a meta-analysis", IZA Discussion Paper 6145.

Gould, D. (1994), "Immigrant links to the home country: empirical implications for U.S. bilateral trade flows", The Review of Economics and Statistics 76(2), 302-316.

Greenaway, D. and Kneller, R. (2007), "Firm heterogeneity, exporting and foreign direct investment", The Economic Journal 117, F134-F161.

Hatzigeorgiou, A. and Lodefalk, M. (2013), "Trade, migration and integration evidence and policy implications", Örebro University School of Business Working Paper 5/2014.

Hiller, S. (2013), "Does immigrant employment matter for export sales? Evidence from Denmark", Review of World Economics 149(2), 369-394. 
Kneller, R. and Pisu, M. (2008), "Export market entry, sunk costs and firm performance", Final Report for UK Trade and Investment.

Marshall, A. (1920), Principles of Economics, 8th edn, London: MacMillan.

Mion, G. and Opromolla, L. (2011), "Managers' mobility, trade status, and wages", CEPR discussion paper 8230 .

Molina, D. and Muendler, M. (2013), "Preparing to export", NBER working paper 18962.

Rauch, J. and Casella, A. (2003), "Overcoming informational barriers to international resource allocation: prices and ties", The Economic Journal 113, 21-42.

Roberts, M. and Tybout, J. (1997), "The decision to export in Columbia: an empirical model of entry with sunk costs", American Economic Review 87(4), 545-564.

Wagner, D., Head, K. and Ries, J. (2002), "Immigration and the trade of the provinces", Scottish Journal of Political Economy 49(5), 507-525.

Wagner, J. (2004), "On the micro-structure of the German export boom: Evidence from establishment panel data, 1995 - 2002", Review of World Economics 140(3), 496-509.

Wagner, J. (2008), "A note on why more West than East German firms export", International Economics and Economic Policy 5(4), 363-370.

Wichert, L. and Wilke, R. (2009), "Analysis of missclassification in register data - the case of education and citizenship in German employment records", Mimeo, University of Nottingham.

Wooldridge, J. (2010), The econometric analysis of cross section and panel data, second edn, MIT Press, Cambridge MA. 


\section{Appendix A Measurement error in nationality}

The nationality information in the Beschäftigtenstatistik refers in principle to "citizenship". Thus, an individual may have foreign citizenship despite being born in Germany; an individual may also have German citizenship despite being born outside Germany. Ideally, we would classify individuals according to the strength of ties to other countries. This seems most likely to be captured by their country of birth. Changes in citizenship over time may therefore be genuine in some cases, suggesting that the imputation procedure suggested by Wichert and Wilke (2009) will not useful in this case.

To measure the amount of reclassification in the nationality variable, we take the complete samples of the Beschäftigtenstatistik for each year $(t=1975 \ldots 2006)$ and compare them to the following year $(t+1=1976 \ldots 2007)$. Let $N_{i t}$ be the nationality variable. A dummy variable $C_{i t}$ is defined as $1\left(N_{i t} \neq N_{i t+1}\right) . \quad E\left(C_{i t} \mid N_{i t}\right)$ is the proportion of workers of nationality $N$ at time $t$ who are no longer that nationality a year later. $E\left(C_{i t} \mid N_{i t+1}\right)$ is the proportion of workers of nationality $N$ at time $t+1$ who were not that nationality a year before. The highest reclassification rates are among migrants from the former Soviet states and the former Yugoslavia. This is entirely unsurprising and we correct for this simply by grouping nationalities appropriately. After removing these groups, Figure A1 shows the percentage of the sample who are reclassified between successive years for all nationalities with more than 5,000 observations per year in the

\section{Beschäftigtenstatistik.}

Figure A1: Percentage of sample who change nationality between $t$ and $t+1$ for all nationalities with more than 5000 observations per year.

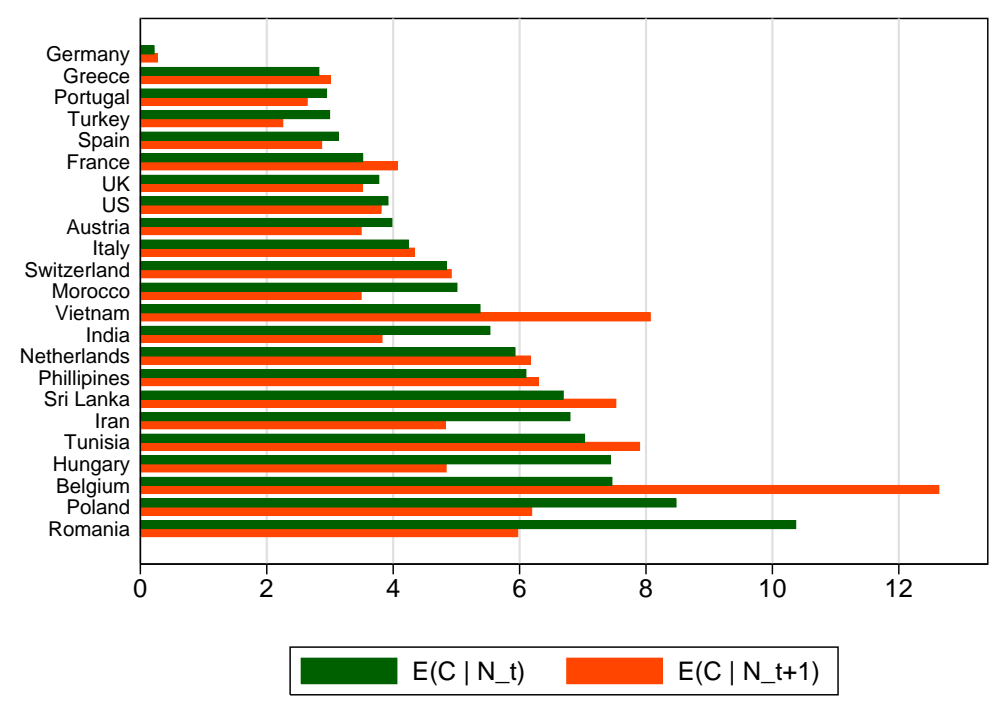


If these reclassifications were genuine changes in citizenship then we would expect to find much higher rates of $E\left(C_{i t} \mid N_{i t}\right)$ than $E\left(C_{i t} \mid N_{i t+1}\right)$, but in general this is not the case. For example, about 3\% of Turks are coded as non-Turkish the following year, but over $2 \%$ of Turks were non-Turkish in the previous year.

Because of these changes in nationality (which we think are mainly miss-classifications) we adopt two different "cleaned" measures of nationality and check to make sure that our baseline results are robust to these definitions. Our preferred measure is to use the proportion of time that an individual is coded as their most common (non-German) nationality. This definition therefore places a higher weight on individuals who are consistently recorded as being a particular nationality. For example, an individual who appears 10 times in the social security data and is coded as being French in one of those years and German in the remaining nine is coded as $F_{i}=0.1$. We also define $F_{i}$ to be the individual's nationality in the first year in which they appear in the social security data, which is intended to correct for the fact that individuals may change their nationality over time. A comparison of the base model when these two definitions are used is shown in Table A1, which shows that the basic result is robust to definition of $F_{i}$. 
Table A1: OLS estimates of base model with different definitions of "foreign". Column (1) repeats the base model estimate, which uses our preferred definition as the proportion of time that an individual is recorded as being nonGerman. Column (2) uses the nationality reported in the first year.

\begin{tabular}{|c|c|c|}
\hline Measure of foreign & $\begin{array}{l}(1) \\
\text { Proportion of } \\
\text { time foreign }\end{array}$ & $\begin{array}{l}\text { (2) } \\
\text { Foreign in } \\
\text { first year }\end{array}$ \\
\hline $\bar{F}_{j t-1}$ & $\begin{array}{l}0.226^{* * *} \\
(0.041)\end{array}$ & $\begin{array}{l}0.192^{* * *} \\
(0.040)\end{array}$ \\
\hline Foreign-owned & $\begin{array}{l}0.161^{* * *} \\
(0.011)\end{array}$ & $\begin{array}{l}0.162^{* * *} \\
(0.011)\end{array}$ \\
\hline Distance to border & $\begin{array}{c}-0.019^{* * *} \\
(0.007)\end{array}$ & $\begin{array}{c}-0.019^{* * *} \\
(0.007)\end{array}$ \\
\hline Border district & $\begin{array}{l}0.050^{* * *} \\
(0.010)\end{array}$ & $\begin{array}{l}0.051^{* * *} \\
(0.010)\end{array}$ \\
\hline Eastern Germany & $\begin{array}{c}-0.102^{* * *} \\
(0.006)\end{array}$ & $\begin{array}{c}-0.103^{* * *} \\
(0.006)\end{array}$ \\
\hline Firm organisation (2) & Yes & Yes \\
\hline Urbanicity (9) & Yes & Yes \\
\hline Industry (10) & Yes & Yes \\
\hline Size classes (9) & Yes & Yes \\
\hline Year (15) & Yes & Yes \\
\hline Occupation (9) & Yes & Yes \\
\hline District (439) & No & No \\
\hline District-year (6212) & No & No \\
\hline$R^{2}$ & 0.345 & 0.345 \\
\hline Number of obs. & 83,756 & 83,756 \\
\hline Number of establishments & 20,700 & 20,700 \\
\hline
\end{tabular}

Standard-errors in parentheses are clustered at the establishment level. ${ }^{* * *}$ indicates $p<0.01,{ }^{* *}$ indicates $0.01 \leq p<$ 0.05 and $^{*}$ indicates $0.05 \leq p<0.1$. 


\section{Appendix B Occupational titles}

Table B1: Occupational coding. Table shows the most common occupations within each 1-digit occupation code, together with the proportion of employment in that occupation.

\begin{tabular}{|c|c|}
\hline Occupation group & Most common occupational titles \\
\hline Basic manual occupations & $\begin{array}{l}\text { Chemical establishment operatives }(9 \%) \\
\text { Metal workers }(9 \%) \\
\text { Assistants }(8 \%) \\
\text { Goods examiners, sorters }(6 \%) \\
\text { Electrical parts assemblers }(6 \%) \\
\text { Packagers, goods receivers, dispatchers }(5 \%) \\
\text { Other assemblers }(5 \%) \\
\text { Plastics processors }(4 \%)\end{array}$ \\
\hline Qualified manual occupations & $\begin{array}{l}\text { Electrical fitters, mechanics }(13 \%) \\
\text { Engine fitters }(12 \%) \\
\text { Establishment fitters }(10 \%) \\
\text { Turners }(7 \%) \\
\text { Toolmakers }(6 \%) \\
\text { Motor vehicle repairers }(5 \%)\end{array}$ \\
\hline Engineers and technicians & $\begin{array}{l}\text { Other technicians }(18 \%) \\
\text { Mechanical engineers }(13 \%) \\
\text { Electrical engineers }(11 \%) \\
\text { Foremen, master mechanics }(10 \%)\end{array}$ \\
\hline Basic service occupations & $\begin{array}{l}\text { Stores and transport workers }(25 \%) \\
\text { Motor vehicle drivers }(20 \%) \\
\text { Warehouse managers, warehousemen }(19 \%)\end{array}$ \\
\hline Qualified service occupations & $\begin{array}{l}\text { Railway drivers }(28 \%) \\
\text { Railway controllers and conductors }(21 \%) \\
\text { Firefighters }(18 \%) \\
\text { Hairdressers }(9 \%)\end{array}$ \\
\hline Associate professional & $\begin{array}{l}\text { Journalists }(41 \%) \\
\text { Librarians, archivists }(14 \%) \\
\text { Technical and vocational instructors }(11 \%) \\
\text { Other teachers }(9 \%)\end{array}$ \\
\hline Professional & $\begin{array}{l}\text { Social scientists, statisticians }(41 \%) \\
\text { Visual and commercial artists }(14 \%) \\
\text { Legal representatives and advisors (11\%) } \\
\text { Interior designers }(10 \%) \\
\text { Pharmacists }(5 \%)\end{array}$ \\
\hline Basic business occupations & $\begin{array}{l}\text { Salespersons }(37 \%) \\
\text { Commercial agents }(22 \%) \\
\text { Typists }(22 \%) \\
\text { Office auxiliary workers }(10 \%)\end{array}$ \\
\hline Qualified business occupations & $\begin{array}{l}\text { Office specialists }(67 \%) \\
\text { Data processing specialists }(13 \%) \\
\text { Wholesale and retail trade buyers }(12 \%) \\
\text { Accountants }(4 \%)\end{array}$ \\
\hline Managers & $\begin{array}{l}\text { Entrepreneurs, managing directors, divisional managers }(67 \%) \\
\text { Management consultants, organisers }(16 \%) \\
\text { Chartered accountants }(9 \%)\end{array}$ \\
\hline
\end{tabular}

